\title{
Public Service Performance in Land Offices of Barito Kuala District
}

\author{
Sumiyati ${ }^{1 *}$, Muslih Amberi ${ }^{1}$, Rahma Yuliani ${ }^{1}$
}

${ }^{1}$ Master Program of Public Administration, Lambung Mangkurat University, Banjarmasin, Indonesia

DOI: $10.36348 /$ sjef.2021.v05i02.008

| Received: 10.02.2021 | Accepted: 22.02.2021 | Published: 26.02.2021

*Corresponding author: Sumiyati

\section{Abstract}

This research was conducted at the Barito Kuala Regency Land Office with the aim of: (1) Determining the performance of public services that have been implemented and whether these services are in accordance with existing procedures; (2) Knowing what factors hinder the performance of the Barito Kuala Regency Land Office services. This study used descriptive qualitative method. The results showed that the quality of service performance at the Barito Kuala Regency Land Office was still low. This can be seen from the phenomena contained in the dimensions of responsiveness, responsibility, and accountability. These three dimensions have not been implemented optimally.

Keyword: Service dimension, service performance, land office.

Copyright (C) 2021 The Author(s): This is an open-access article distributed under the terms of the Creative Commons Attribution 4.0 International License (CC BY-NC 4.0) which permits unrestricted use, distribution, and reproduction in any medium for non-commercial use provided the original author and source are credited.

\section{INTRODUCTION}

The Ministry of Agrarian Affairs and Spatial Planning/National Land Agency is a government agency that functions in the land sector regionally, nationally and sectorally. The Ministry of Agrarian Affairs and Spatial Planning/National Land Agency is known as the Agrarian Office. In a Regency/City area it is known as the Land Office. The duties and functions of the Land Office are to carry out land services to the community, so that what becomes the center of public attention is of course related to the implementation of services at the Land Office. Based on this, it is necessary to pay attention to improving these services, in an effort to cover a very broad aspect, starting from the policy level which of course includes curbing regulations to the level of implementation.

Article 33, section (3) of the 1945 Constitution constitutes the principle that the earth and water and the natural resources contained therein are controlled by the State and used maximally for the prosperity of the people. Then the government issued the Basic Agrarian Law (UUPA) or better known as Law Number 5 of 1960 which came out on September 24, 1960, which regulates land in Indonesia with the aim of being a clear legal basis for ownership. Right to Land, and the State as the highest authority over the people, is obliged to:

1. Regulation and completion of the use, designation, preparation and maintenance of earth, water and space;
2. Regulation and stipulation in legal matters between people and the earth, water and space;

3. Regulation and stipulation of legal relations between people and legal acts that are integral to the control of earth, water and space.

This Basic Agrarian Law is further regulated in Government Regulation Number 24 of 1997 concerning Land Registration which states that there are 2 (two) main obligations, namely:

1. The government has the obligation to carry out land registration throughout the territory of the Republic of Indonesia;

2. Holders of Land Rights have an obligation to include the Land Rights they hold.

Participating parties will recognize the subject of the land and the object of the land when registration of their land rights is carried out, because it will be known about the person who is the holder of the land title, where the land is located, the boundaries of the land regarding the length and width. As proof of legal ownership a "Land Certificate" will be issued. A certificate is a land book and a measuring document that has been bound together, with a cover paper whose design has been approved by a Government Regulation.

The owner of a land certificate is the holder of full ownership rights to the land so that no one can sue if the certificate is "aged" five years. At the age of less than five years, other parties who do have proof of 
ownership with the same degree of legal force are still given the opportunity to contest the control of land rights or sue ownership. The affirmation is listed if we understand from the sound of Government Regulation Number 24 of 1997 Article 32:

1. A certificate is a proof of rights which functions as a strong means of proof with respect to the physical data and juridical data contained therein, as long as the physical data and juridical data are uniform with the data contained in the measuring letter and the relevant land title book.

2. In the case of a parcel of land that has been legally issued a certificate in the name of the person or legal entity who obtained the land with good confidence and visibly controls it, so that other parties who think that they have rights to the land can no longer claim the exercise of said rights, if within 5 (five) years since the issuance of the certificate, there is no written protest to the official of the certificate and the head of the Land Office concerned or does not submit a lawsuit to the Court regarding control of the land or the issuance of the certificate.

The problem in terms of service has very broad dimensions with various modes of implementation in various situations [4]. From the example of the case at the Barito Kuala Regency Land Office, it shows that the problem of public services in making land certificates is one of the main problems for the institution that must be resolved immediately. In order not to receive further attention in this reform era, the performance of services at the Barito Kuala Regency Land Office must be immediately evaluated, so that obstacles that affect service performance at the Land Office can be found and overcome. In addition, the image of the developing community that administering a certificate at the Land Office is expensive and takes a long time to be removed from the minds of the wider community.

Lack of coordination and good communication between sections also causes a long time to complete the certificate, because the work on the certificate is like a running wheel. If it stops at one section, the file cannot be forwarded to the next section. The issue of land boundaries or what is commonly called a land ownership boundary mark is also a problem at the Barito Kuala Regency Land Office. Land boundaries may change or be intentionally changed by parties trying to take someone else's land rights, for example by shifting existing land markers or boundaries. This of course will be a conflict between the land owner and the party trying to take away the land rights.

Therefore, the researcher wants to know: (1) The performance of public services that have been implemented and the service is in accordance with existing procedures in the context of responsiveness, responsibility, and accountability; (2) What factors are hindering the performance of the Barito Kuala Regency Land Office services.

\section{METHOD}

This study used a qualitative descriptive method, namely research conducted to determine the specific characteristics of a group [1]. The qualitative method in this study is characterized by the collection of data and information as much as possible, as well as making direct observations of the service process carried out. The quantitative method is characterized by extracting data through direct observation of the selected object of research.

\section{RESULTS AND DISCUSSION}

The logical consequence for the Barito Kuala Regency Land Office as a public service organization is to place the community or applicant as the most important factor in carrying out their duties. Control by the public as service users can be used as a way of assessing whether or not the service performance provided by the public service organization is good for the public. This public perception was taken from the results of the author's interviews with several applicants, both those who happened to be at the Barito Kuala Regency Land Office, as well as the applicants whom the author had determined based on available data and documents.

\section{Responsiveness}

Responsiveness in this study is seen from how the efforts and actions taken by the Barito Kuala Regency Land Office to make improvements to the needs and desires of the community/applicants as service users, as well as the placement of service users by bureaucratic officials in the applicable service system.

One of the efforts of the Barito Kuala Regency Land Office is to establish land service counters. In order to provide services through the counter system, in the Barito Kuala Regency Land Office, in addition to service counters, a waiting room has been provided for the community and information boards and land flow charts are made, equipped with:

- Document requirements needed for each type of service activity.

- The amount of fee is in accordance with the applicable fee.

- Service completion period.

- Legal Basis.

In its operation, the responsiveness of public services is translated into several indicators, such as (1) the attitude of bureaucratic officials in responding to complaints from service users; (2) the use of complaints from service users as a reference for improving service delivery in the future; (3) various actions of the bureaucratic apparatus to provide service satisfaction to 
Sumiyati et al., Saudi J Econ Fin, Feb, 2021; 5(2): 80-84

service users; and (4) placement of service users by bureaucratic officials in the applicable service system [2].

The following is an interview with a respondent, an employee at the Barito Kuala Regency Land Office, the Head of the Sub-Section of Land Control who is the counter manager, can be described as follows:

For the problem of the needs or desires of the applicant as a service user, actually it can be seen and is completely available in the information box and the land service flow chart is already available. For the coordinator/manager, the counter officers are carried out in turns every month. If there is a petitioner who comes with a complaint about a land case/dispute, we submit it to formally write and submit it to the complaint counter that is available, from the complaint will be mediated to the parties to help resolve the problem.

This statement implies that the services at the Barito Kuala Regency Land Office have tried to be responsive. In order to improve the quality of service to the community as a form of response to complaints and aspirations of the community, there are service counters consisting of 4 counters according to the stages of the management procedure and also every month in turn appointed counter coordinator officers and other counter officers. Then the person concerned also said:

There are applicants who have come to the Barito Kuala Regency Land Office to submit requests that we cannot accept and must reject. One of the examples is the application for the return of the inheritance name, the applicant has brought the application file. After being checked and examined by officers at the office, it turned out that there were still shortcomings, namely the approval of all heirs. This, of course, is very basic and we cannot accept it in the office, because of course the request for settlement cannot be continued. Indeed, this certainly disappointed the applicant, because he had to go back and forth to the Land Office to take care of the petition.

In the service case above, there was a rejection of the application file from the community/applicant because of the ignorance of the applicant/community as service users regarding the terms and procedures in the application service that they will perform at the Barito Kuala Regency Land Office. This of course disappointed the applicant/community because they had to go back and forth to the Land Office to process their petition. This implies that the services at the Land Office are still unable to convey information externally to the public/applicants as service users.

\section{Responsibility}

Responsibility in this case is seen from the ease of submitting a land certificate application, the ease in measuring and mapping the location, the speed of the apparatus in making measuring letters, the speed in land inspection, and the accuracy in issuing land certificates.

The important points to make are looking at the service responsibility and the process of submitting a Land Certificate application.

The service counter room consists of 4 counters consisting of:

- Counter I : Information Counter and Land Issues.

- Counter II : Technical Activity Service Counter (application submission).

- Counter III : Payment/finance counter.

- Counter IV : Work Result Submission Counter.

- Counter V : Problem Complaints Counter.

The applicant gets information about all the requirements at counter $I$, if the requirements have been completed then it is entered at the right service application counter to obtain the accuracy of the submitted files. If there is still a lack of requirements, the applicant is asked to complete it again. In connection with the operationalization of the counter system, many things have been experienced and felt by officers and the community, including the lack of service counter officers so that officers serve concurrently at different counters [3].

Based on the interview with the counter clerk, it was stated:

"Due to the shortage of staff at the Barito Kuala Regency Land Office, our counter officers are still working at the service counter, even though every week there are counter managers who work in turns. But sometimes we are in the booth asking for help from measuring officers and SK making officers to serve the applicant's questions at the counter. "

Furthermore, in this study the author also asked for the opinion of one of the applicants as follows:

"Right now I want to immediately complete all the requirements, but it turns out that there are several files that I need to consult again with you... .. (mentioning one of the employees in the Barito Kuala district land office environment), because the counter clerk did not understand the problem of one of the files completeness. me. The man said that he still had a need that I didn't tell me, so I had to wait more than 1 hour. " 
This implies that the officers at the counter are still not in control and can respond quickly to the wishes of the applicant in completing his application documents.

\section{Accountability}

Accountability in the sense here is how the Land Office through its service apparatus provides services in a transparent and clear manner as in one of the principles of land services, namely the principle of openness. In this case transparency of costs, time, procedures and data and information.

The accountability of public service delivery in this study is seen through performance indicators which include: (1) Service references used by officers at the Barito Kuala Regency Land Office in the process of providing public services. These indicators reflect service orientation principles developed by the bureaucracy towards service users; (2) Actions taken by service officers if there are service users who do not meet the specified requirements; and (3) in carrying out service tasks, to what extent the interests of the applicant/community get priority from bureaucratic officers/officials.

With regard to accountability in services at the Barito Kuala Regency Land Office, a staff member at the Land Law Relations section stated as follows:

"There are 3 petitioners who utilize land services, namely, Notary/PPAT, the general public and village/sub-district officials. Based on the several service groups, there is absolutely no difference in service for all applications according to applicable regulations. It's just that the fact is that many of the general public do not want to be bothered so that they empower the parties, even though the consequence is that the applicant has to pay higher service fees than to go to the Land Office himself. Actually, we, from the Land Office, want people to come directly to the Land Office so that people can understand what and how land problems are. Because services at the Land Office are open public services, all requests as long as they meet the requirements will still be accepted."

"In service to the applicant, of course, we apply the service according to the standards set according to the SOPP and the operational guidelines (operational guidelines) that have been determined, so if an applicant turns out to be deficient, of course we cannot accept it for further processing."

From the interview, it can be seen that the accountability of public services at the Barito Kuala Regency Land Office is still low. Bureaucratic officials in providing services often still apply standard values or service norms unilaterally, such as providing services based only on operational guidelines (implementation guidelines) so that the tendency that occurs is the weak commitment of service officers to be accountable to the people they serve.

The low accountability of public service delivery by the Barito Kuala Regency Land Office can be seen from the many cases experienced by service users. Service procedure problems that are detrimental to many service users, especially the problem of transparency of the required requirements.

Then to find out the information from the applicant, the following is an interview with one of the applicants:

"I want to change the name from my mother's name to my name, because this is family land. As instructed by the BPN employee, this means that measurements and remapping and deeds must be carried out through a notary public. I have fulfilled all the requirements, but when the measurement was going to be carried out, there was another request from the officer because my land was very large, so there was an additional cost for measurements in the field. Because I wanted to get it sorted out quickly, it was with a heavy heart that I was forced to fulfill the request."

This acknowledgment from the community implies that the services at the Barito Kuala Regency Land Office are becoming expensive, because there are additional services that must be paid. This happened because the community/applicant did not know the actual procedure and fees to be paid because apparently there were still stages in submitting an application which they thought was only one stage.

\section{CONCLUSION}

The service performance at the Barito Kuala Regency Land Office is still low. This can be seen from the phenomena contained in the dimensions of responsiveness, responsibility, and accountability. Based on the three dimensions, it is still found that the dimensions have not run optimally. This is because some problems are still found in this dimension, namely, the limited number of human resources available, as well as unclear/long time to complete the given task.

This is also due to the fact that there are too many targets for the realization of the sectors set by the government that do not match the number of resources and facilities available at the Barito Kuala Regency Land Office. There are two obstacles faced in the service at the Barito Kuala Regency Land Office, namely external and internal constraints. For internal constraints, it can be stated as follows: (1) There are difficulties for the applicant to present a party that is bordering, so that there is no signature of the adjacent party, and there is no land boundary stake so that measurements cannot be carried out; (2) Difficulty in the terrain/location of the land that is difficult to reach 
Sumiyati et al., Saudi J Econ Fin, Feb, 2021; 5(2): 80-84

to carry out the measurement; and (3) The limited number of measuring officers is not comparable to the measurement targets at the Barito Kuala Regency Land Office.

\section{REFERENCE}

1. Sugiyono. (2009). Metode Penelitian Pendekatan Kuantitatif, Kualitatif, R\&D. Bandung: Alfabeta
2. Dwiyanto, A. (2002). Reformasi Birokrasi Publik di Indonesia. Yogyakarta: Pusat studi Kependudukan dan Kebijakan UGM.

3. Moenir. (1992). Manajemen Pelayanan Umum di Indonesia. Jakarta: Bumi Aksara.

4. Bintoro, T., \& Mustopadiadjaya, A.R. (1983). Teori Strategis Pembangunan Nasional, Jakarta: Gunung Agung. 